\title{
The R. F. Wallace Farm (41CE20) and W. T. Brooks Farm (41CE18) Sites in the Neches River Basin, Cherokee County, Texas
}

Timothy K. Perttula

Follow this and additional works at: https://scholarworks.sfasu.edu/ita

Part of the American Material Culture Commons, Archaeological Anthropology Commons, Environmental Studies Commons, Other American Studies Commons, Other Arts and Humanities Commons, Other History of Art, Architecture, and Archaeology Commons, and the United States History Commons

Tell us how this article helped you.

This Article is brought to you for free and open access by the Center for Regional Heritage Research at SFA ScholarWorks. It has been accepted for inclusion in Index of Texas Archaeology: Open Access Gray Literature from the Lone Star State by an authorized editor of SFA ScholarWorks. For more information, please contact cdsscholarworks@sfasu.edu. 


\section{The R. F. Wallace Farm (41CE20) and W. T. Brooks Farm (41CE18) Sites in the Neches River Basin, Cherokee County, Texas}

\section{Creative Commons License}

\section{(c) (1) \&}

This work is licensed under a Creative Commons Attribution-NonCommercial 4.0 International License 


\title{
The R. F. Wallace Farm (41CE20) and W. T. Brooks Farm (41CE18) Sites in the Neches River Basin, Cherokee County, Texas
}

\author{
Timothy K. Perttula
}

\section{Introduction}

The R. F. Wallace Farm (41CE20) and W. T. Brooks Farm (41CE18) sites are ancestral Caddo sites in the Neches River basin in the East Texas Pineywoods, not far to the north and northwest, respectively, from the well-known Caddo village and mound center at the George C. Davis site (41CE19) (Figure 1). Both sites are on tributaries to the Neches River: the R. F. Wallace Farm site is on Bowles Creek, and the W. T. Brooks Farm site is on Box's Creek.

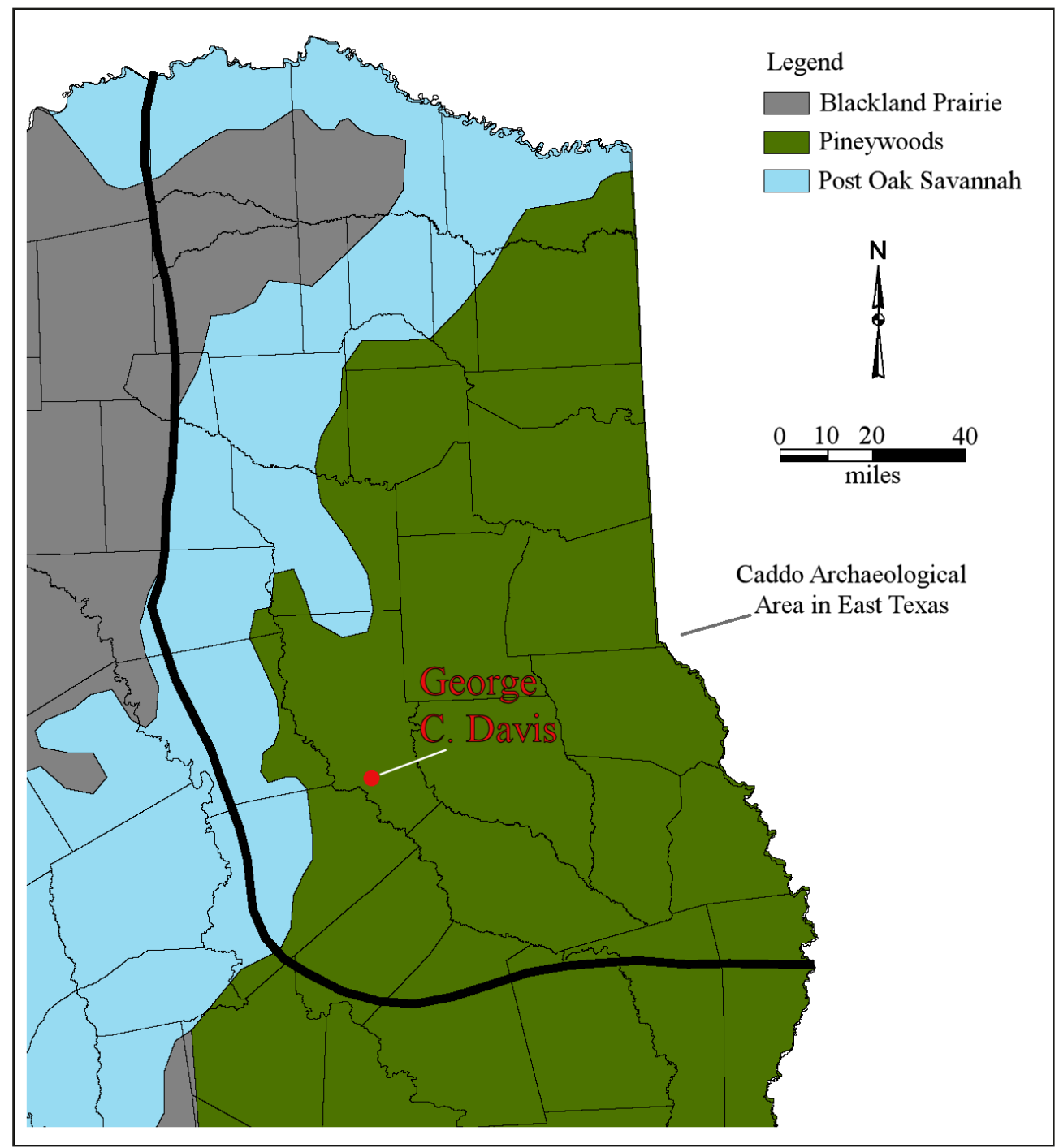

Figure 1. The location of the George C. Davis site in Cherokee County in East Texas. 
Archaeologists at the University of Texas learned about both sites in the early 1930s from information provided by the landowners. Artifact collections and site files from both sites are held by the Texas Archeological Research Laboratory at The University of Texas at Austin (TARL). These collections and files are employed in this article to discuss the archaeological findings from both sites.

\section{The R. F. Wallace Farm Site (41CE20)}

In the spring of 1930, after flooding along Bowles Creek and White Oak Creek, skeletal materials and two ceramic vessels (an engraved bottle and a bowl) had been washed out from the R. F. Wallace Farm site. The R. F. Wallace Farm sits in the floodplain at the confluence of Bowles and White Oak creeks, on the east side of White Oak Creek (Figure 2), little more than $1.2 \mathrm{~km}$ north of the George C. Davis site.

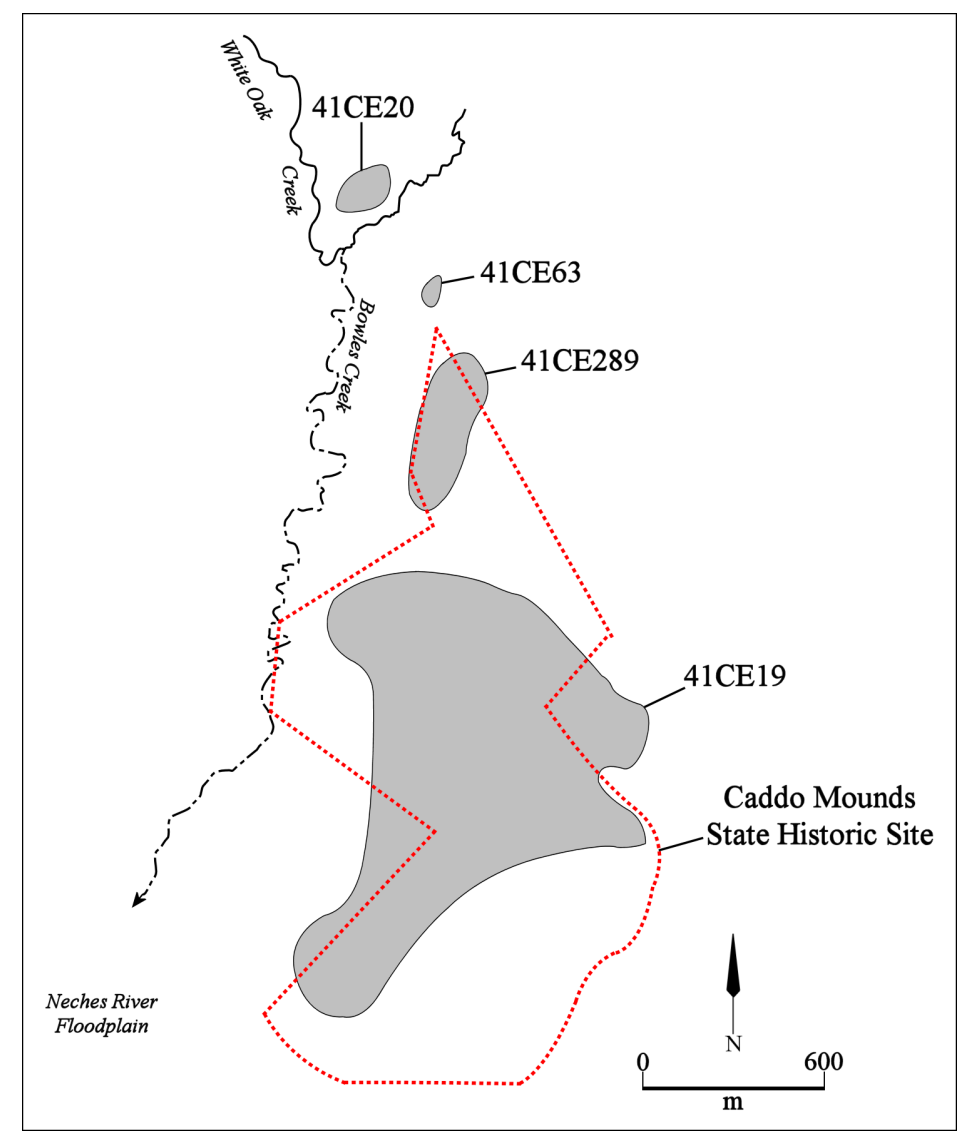

Figure 2. The location of the R. F. Wallace Farm (41CE20), and other nearby ancestral Caddo sites, including the George C.

Davis site (41CE19), 41CE63, and 41CE289.

A. T. Jackson (1932) conducted archaeological investigations at the R. F. Wallace Farm site in June 1932. His excavations, which covered a $26 \times 36 \mathrm{ft}$. area $(8 \times 11 \mathrm{~m})$ where the ancestral Caddo burial had washed out in 1930 (Figure 3). His excavations did not identify any other Caddo burial features (other than pieces of a human jaw) but he did document ancestral Caddo habitation deposits from 0.7-2.8 ft. bs $(20-86 \mathrm{~cm}$ bs) in the excavation area, mainly ceramic vessel sherds. Two glass beads were also found in the excavation area (although they are not presently in the TARL collections), but no information is available on their size or color; it is likely that these two beads relate to the early Historic Allen phase (ca. A.D. 1680-1700) occupation at the R. F. Wallace Farm site. 


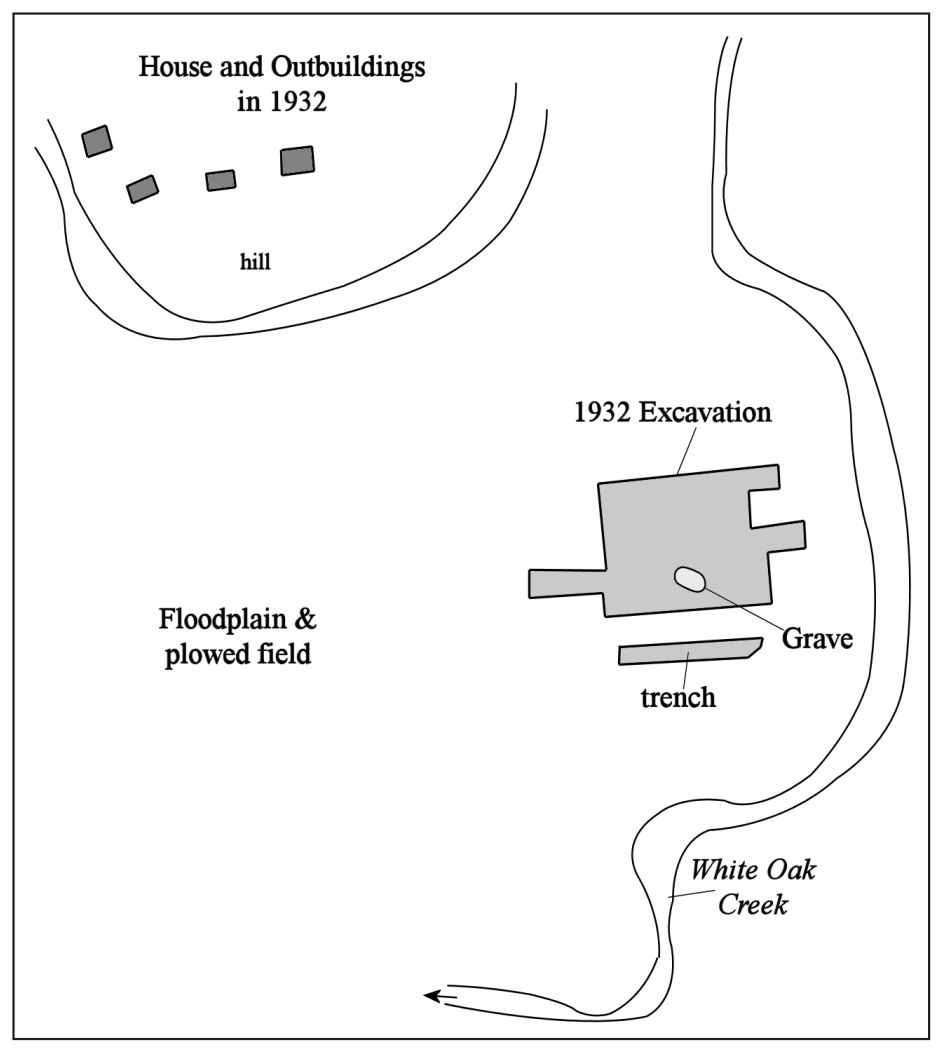

Figure 3. Excavations at the R. F. Wallace Farm site (see Jackson 1932).

\section{Ceramic Vessel Sherd Assemblage}

The ceramic vessel sherd assemblage from the R. F. Wallace Farm site has 261 sherds from plain ware, utility ware, and fine ware vessels (Table 1). More than 74 percent of the sherds are from vessels with either wet paste (i.e., utility ware) or engraved fine wares. The plain to decorated sherd ratio is a low 0.35 , and almost 90 percent of the decorated sherds are from utility wares.

Table 1. Ceramic wares and temper categories in the R. F. Wallace Farm (41CE20) ceramic assemblage.

\begin{tabular}{lllllllll}
\hline Ware & SP & G & G-B & G-H & G-H-B & B & B-H & N \\
\hline Plain & 4 & 45 & 2 & 12 & 1 & 3 & - & 67 \\
Utility & - & 154 & 11 & 2 & - & 6 & 1 & 174 \\
Fine & - & 18 & - & 2 & - & - & - & 20 \\
\hline Totals & 4 & 217 & 13 & 16 & 1 & 9 & 1 & 261 \\
\hline
\end{tabular}

$\mathrm{SP}=$ sandy paste; $\mathrm{G}=$ grog; $\mathrm{G}-\mathrm{B}=$ grog-bone; $\mathrm{G}-\mathrm{H}$, grog-hematite; $\mathrm{G}-\mathrm{H}-\mathrm{B}=$ grog-hematite-bone; $\mathrm{B}=$ bone; $\mathrm{B}-\mathrm{H}=$ bone-hematite

Four of the sherds in the assemblage (1.5 percent) are from sandy paste Goose Creek Plain, var. unspecified vessels (see Table 1). These are from use of the R. F. Wallace Farm site by Mossy Grove Woodland period peoples between ca. 500 B.C. and A.D. 800 (see Story 1990; Ellis 2013). 
The remainder of the ceramic sherds $(n=257)$ are from the ancestral Caddo settlement of the site. These vessel sherds are from vessels tempered with various combinations of grog, bone, or hematite (see Table 1). More than 83 percent of the sherds are tempered solely with grog (i.e., crushed sherds); 5 percent are from vessels tempered with grog and bone; another 6 percent are tempered with grog and hematite (particularly plain wares); and 0.4 percent have grog, bone, and hematite temper inclusions. About 4 percent of the ceramic sherds are from vessels tempered with burned bone and/or hematite (see Table 1). Considering the use of multiple tempers in the manufacture of ceramic vessels at the R. F. Wallace Farm site, 96 percent of the sherds have grog temper, 9.3 percent have bone temper, and 7.0 percent have hematite temper inclusions. The uses of different tempers in vessel manufacture, but the overall dominance of grog-tempered vessel sherds at the R. F. Wallace site is consistent with other ancestral Caddo sites in this part of the Neches River basin (Perttula and Stingley 2017:Table 22).

Approximately 89.7 percent of the decorated sherds in the R. F. Wallace Farm site assemblage are from utility wares, particularly sherds from vessels with either brushed or brushed-incised decorative elements (Table 2). Ninety-five percent of the fine ware sherds have engraved elements, and the remaining 5 percent have engraved and brushed decorative elements.

Table 2. Decorative methods and elements on the utility ware and fine ware sherds from the R. F. Wallace Farm site (41CE20).

\begin{tabular}{llll}
\hline Decorative method and elements & Rim & Body & $N$ \\
\hline
\end{tabular}

\section{Utility Ware}

\section{Brushed}

diagonal brushed marks

diagonal opposed brushed marks

horizontal brushed marks

horizontal-diagonal brushed marks

opposed brushed marks

overlapping brushed marks

parallel brushed marks

vertical brushed marks

\section{Brushed-Appliqued}

opposed-curvilinear brushed marks-curvilinear appliqued fillet

parallel brushed-parallel appliqued fillets

\section{Brushed-Incised}

diagonal incised lines [rim]-diagonal brushed [body]

horizontal brushed-incised marks and lines

horizontal brushed marks-diagonal overlapping

incised lines

opposed brushed-incised marks and lines

overlapping brushed-incised marks and lines

parallel brushed marks-overlying opposed incised lines

parallel brushed-incised marks and lines

parallel brushed-incised marks and lines and overlying

opposed incised lines

vertical brushed-incised marks and lines

$\begin{array}{ll}1 & 2 \\ 1 & 1 \\ - & 3 \\ 1 & 1 \\ 3 & 3 \\ 3 & 3 \\ 83 & 83 \\ 1 & 1\end{array}$

2

3

1

3

$\begin{array}{lll}- & 1 & 1 \\ - & 1 & 1 \\ 1 & - & 1 \\ - & 6 & 6 \\ - & 3 & 3 \\ - & 12 & 12 \\ - & 24 & 24 \\ - & 1 & 1 \\ - & 1 & 1\end{array}$


Table 2. Decorative methods and elements on the utility ware and fine ware sherds from the R. F. Wallace Farm site (41CE20), cont.

\begin{tabular}{llll}
\hline Decorative method and elements & Rim & Body & $N$ \\
\hline
\end{tabular}

Brushed-Incised-Appliqued

parallel-curvilinear brushed-incised marks and lines and parallel appliqued fillets

Brushed-Incised-Punctated

horizontal brushed-incised marks and lines and tool

punctated row near the lip and through the brushing parallel brushed-incised marks and lines and tool

punctated row through the brushing-incised lines

\section{Brushed-Punctated}

horizontal brushed marks-tool punctated row at the lip parallel brushed-tool punctated row through the brushing

\section{Incised}

curvilinear incised lines

set of curvilinear incised lines

horizontal incised line

parallel incised lines

straight incised line

$-$

1

1

\section{Incised-Punctated}

horizontal incised lines-tool punctated row at the lip parallel incised lines-tool punctated zone

parallel incised lines-tool punctated row through the incised lines

\section{Neck Banded}

horizontal neck banded rows (La Rue Neck Banded) straight neck banded row (La Rue Neck Banded)

\section{Punctated}

tool punctated rows

$\begin{array}{lll}2 & - & 2 \\ - & 1\end{array}$

Fine Ware

\section{Engraved}

curvilinear engraved lines

curvilinear engraved lines with tick marks (Patton

Engraved)

diagonal opposed engraved lines (Poynor Engraved)

diagonal opposed engraved lines and concentric

ovals (Poynor Engraved)

horizontal engraved line

horizontal engraved lines, widely-spaced

(cf. Hood Engraved)

horizontal engraved lines and linear tick marks on

bottom line (cf. Patton Engraved) 
Table 2. Decorative methods and elements on the utility ware and fine ware sherds from the R. F. Wallace Farm site (41CE20).

\begin{tabular}{|c|c|c|c|}
\hline Decorative method and elements & Rim & Body & $\mathrm{N}$ \\
\hline $\begin{array}{l}\text { horizontal engraved lines-large excised rectangular } \\
\text { elements pendant from lines (cf. Hume Engraved or } \\
\text { Poynor Engraved) }\end{array}$ & 1 & - & 1 \\
\hline $\begin{array}{l}\text { horizontal and curvilinear engraved lines with tick } \\
\text { marks (Patton Engraved) }\end{array}$ & 1 & - & 1 \\
\hline horizontal-vertical engraved lines (Poynor Engraved) & - & 1 & 1 \\
\hline $\begin{array}{l}\text { horizontal-vertical engraved lines-diagonal hatched } \\
\text { zone (Poynor Engraved) }\end{array}$ & - & 2 & 2 \\
\hline parallel engraved lines & - & 1 & 1 \\
\hline parallel engraved lines, set of & - & 1 & 1 \\
\hline $\begin{array}{l}\text { triangular excised zone and diagonal engraved lines } \\
\text { (Poynor Engraved) }\end{array}$ & - & 1 & 1 \\
\hline \multicolumn{4}{|l|}{ Engraved-Brushed } \\
\hline $\begin{array}{l}\text { horizontal engraved line on panel-horizontal brushed } \\
\text { marks on body }\end{array}$ & - & 1 & 1 \\
\hline Totals & 18 & 176 & 194 \\
\hline
\end{tabular}

The sherds with brushed decorative elements are from Bullard Brushed vessels with brushing marks on both the rim and body (see Suhm and Jelks 1962:Plate 11). They have horizontal and diagonal brushing on the rim, and parallel (vertical), opposed, overlapping, and diagonal brushing marks on the vessel body (see Table 2). The brushed sherds represent 56 percent of the utility ware sherds at the R. F. Wallace Farm and 50 percent of all the decorated sherds from the site.

Two distinctive body sherds in the assemblage have brushed and appliqued decorative elements. One has opposed and curvilinear brushed marks on either side of a curvilinear appliqued fillet (Figure $4 \mathrm{~b}$ ), while the other has parallel brushing marks on either side of parallel appliqued fillets. These sherds compare favorably to Pease Brushed-Incised jars (see Suhm and Jelks 1962:Plate 60).

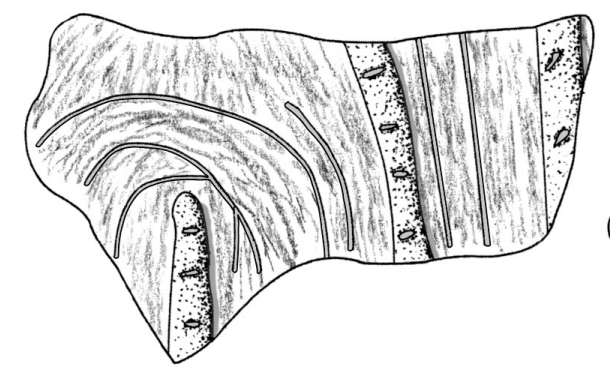

a

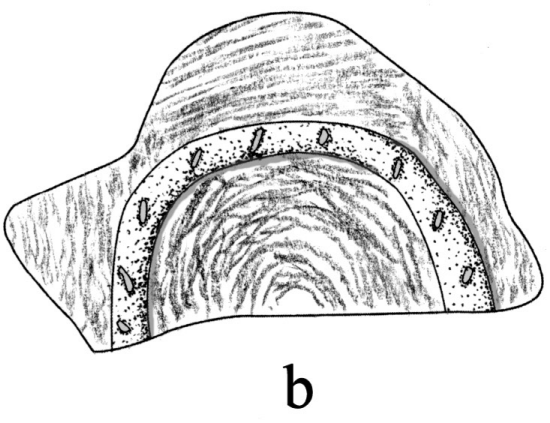

b

Figure 4. Brushed-appliqued and brushed-incised-appliqued body sherds from the R. F. Wallace Farm site (41CE20). 
The sherds with brushed-incised decorative elements comprise approximately 29 percent of the utility wares (see Table 2) About half of these are body sherds with parallel brushed-incised marks and lines. The one brushed-incised rim sherd is from a Spradley Brushed-Incised vessel that has horizontal brushed marks with diagonal overlapping incised lines, while a lower rim-body sherd has diagonal incised lines on the rim and diagonal brushed marks on the vessel body. The brushed-incised marks and lines on the body of vessels are parallel (vertical), diagonal, horizontal, opposed, and overlapping in orientation.

In addition to the previously mentioned Spradley Brushed-Incised rim sherd, the R. F. Wallace Farm utility wares have a number of body sherds ( $\mathrm{n}=12$ or 6.9 percent of the utility ware assemblage) from Spradley Brushed-Incised vessels. These have parallel brushed marks with overlying opposed incised lines. This utility ware is found on Historic Caddo Allen phase sites in the Neches-Angelina river basins in East Texas. It consists of parallel brushing elements with overlapping straight incised lines that are opposed or perpendicular to the brushing (Marceaux 2011:140 and Figure 5.2; Perttula and Selden 2014: Figure 42).

Another probable Pease Brushed-Incised, or Reavely Brushed-Incised (see Hart 2014:63 and Figure 3-9), vessel has parallel and curvilinear brushing marks on either side of parallel appliqued fillets (see Figure $4 \mathrm{a}$ ). Three sherds (1.7 percent of utility wares) from Bullard Brushed vessels have brushedincised-punctated elements, including two rim sherds with a single tool punctated row pushed through the brushed-incised marks and lines near the vessel lip (see Table 2). Two brushed-punctated rim sherds have a tool punctated row at the lip, above horizontal brushed marks on the rim itself; three body sherds have parallel bushed marks with a tool punctated row pushed through the brushing (see Table 2).

Sherds with incised decorative elements account for 5.8 percent of the utility wares at the R. F. Wallace site. Two rim sherds have horizontal incised lines and body sherds have either curvilinear or geometric drawn lines. A number of these sherds may be from Maydelle Incised vessels (see Suhm and Jelks 1962:Plate 52). The sherds with incised-punctated decorative elements (1.7 percent of the utility wares) include a rim sherd with a tool punctated row at the lip and above horizontal incised lines, a Maydelle Incised body sherd with a tool punctated zone bordered by parallel incised lines, and a body sherd with a tool punctated row pushed through parallel incised lines (see Table 2).

Two sherds (1.1 percent of the utility wares) are from La Rue Neck Banded jars with horizontal rows of neck bands on the vessel rim (see Suhm and Jelks 1962:Plate 47). Finally, one utility ware body sherd has rows of tool punctations (see Table 2).

Four different fine ware engraved types are present in the R. F. Wallace Farm ceramic assemblage. One is from a Hood Engraved, var. unspecified vessel (likely from an effigy vessel) with widely-spaced horizontal engraved lines on the rim. One possible Hume Engraved, var. unspecified or Poynor Engraved, var. $C$ (see Perttula 2011:Figure 6-65) vessel has two widely-spaced horizontal engraved lines with large rectangular excised elements pendant from the engraved lines (Figure 5f). Six other sherds are from Poynor Engraved vessels (Figure 5a-e, see Table 2), including a rim with diagonal opposed engraved lines-continuous scroll elements (Figure 5b), a scalloped rim with concentric ovals and diagonal opposed engraved lines (Figure 5a), and three Poynor Engraved, var. Blackburn carinated bowl sherds (Figure $5 \mathrm{c}-\mathrm{e})$. One body sherd with a triangular excised zone and diagonal engraved lines is from a Poynor Engraved bottle.

The fourth fine ware type present in the R. F. Wallace Farm sherds is Patton Engraved, with one rim sherd and six body sherds (see Table 2). One body sherd has at least four horizontal engraved lines, the lowermost of which has linear tick marks; this may be a simplified version of Patton Engraved, var. Allen (see Perttula 2011:Figure 6-66a). The other Patton Engraved sherds have either curvilinear engraved lines with tick marks (Figure 6a, c-d) or horizontal-curvilinear engraved lines with tick marks (Figure 6b). The spacing of curvilinear engraved lines suggest these sheds are from either Patton Engraved, var. Freeman or var. Fair (Perttula 2011:Figure 6-66c-d) 


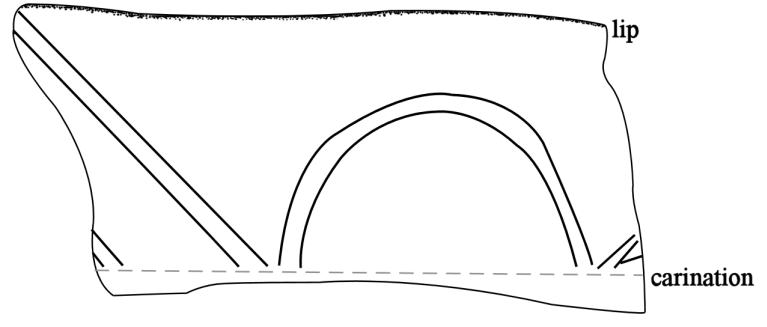

a
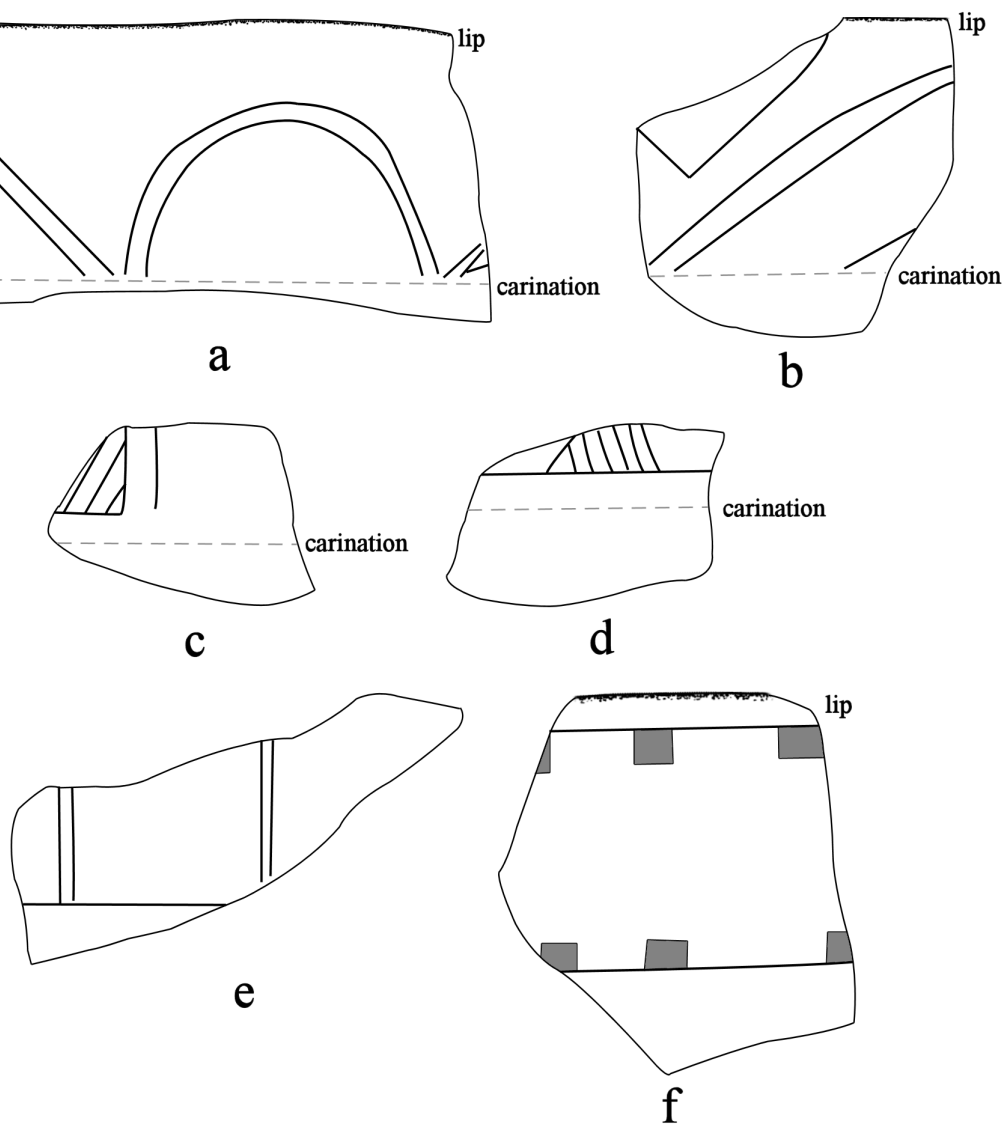

Figure 5. Decorative elements on selected engraved sherds from the R. F. Wallace Farm site.
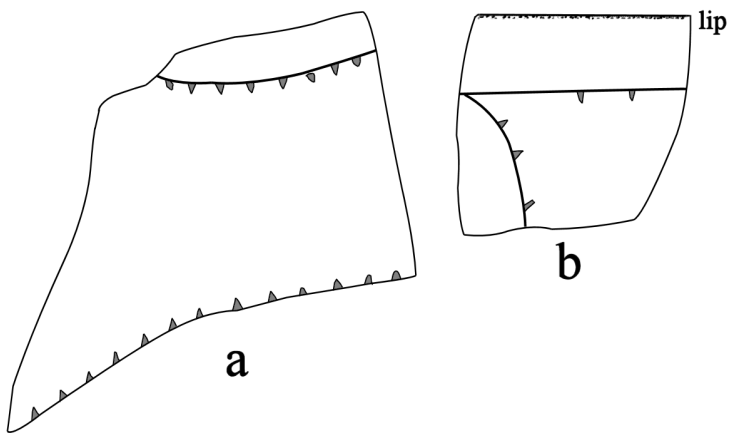

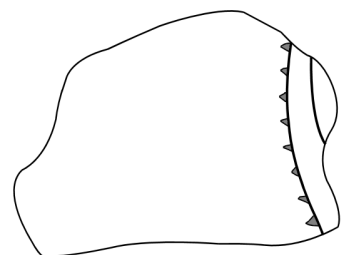

C

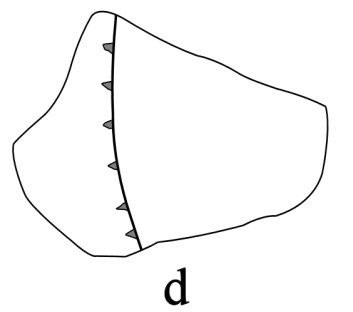

Figure 6. Decorative elements on Patton Engraved sherds from the R. F. Wallace Farm site. 
Engraved-brushed vessels are not uncommon in Frankston and Allen phase fine ware vessels in ancestral Caddo ceramic assemblages in the Neches River basin (see Perttula 2011). One sherd from the R. F. Wallace Farm site is from a carinated bowl with a horizontal engraved line on the rim panel and horizontal brushing marks on the vessel body (see Table 2).

\section{Poynor Engraved Vessel}

The ceramic vessel recovered at the R. F. Wallace Farm site in 1930 is a Poynor Engraved bottle with a short neck and an elongated body (Figure 7; see Suhm and Jelks 1962:Plate 63a-g). the vessel stands 17.3 $\mathrm{cm}$ in height, and has a maximum diameter of $11.5 \mathrm{~cm}$; the orifice diameter is $6.6 \mathrm{~cm}$. The vessel body has vertical panels of curvilinear engraved zones with spurs and circle elements as well as open areas between the panels. There are also three horizontal engraved lines at the top of the vessel body (Figure 7).

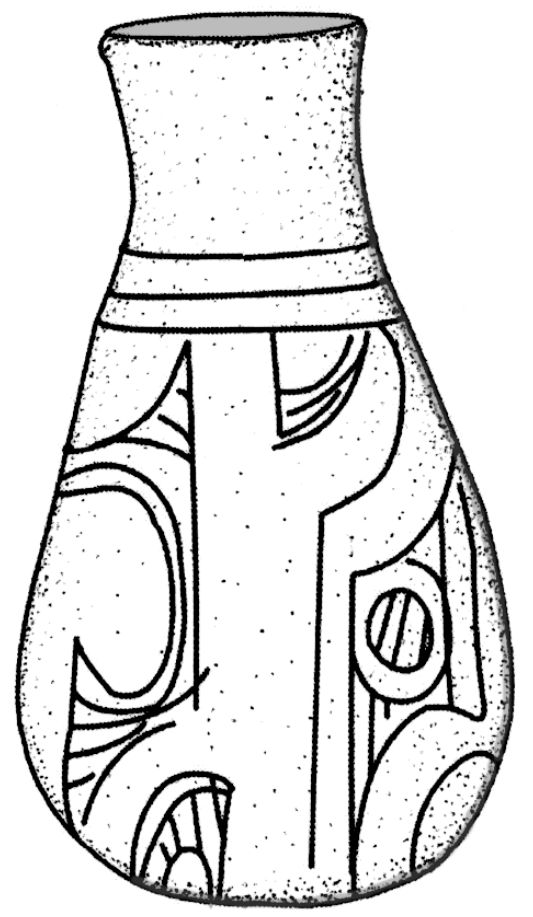

Figure 7. Drawing of the Poynor Engraved bottle from the R. F. Wallace Farm site.

The W. T. Brooks Farm (41CE18)

The W. T. Brooks Farm site is an ancestral Caddo settlement and cemetery in the Box Creek valley; Box Creek is a southward-flowing tributary to the Neches River that joins with the Neches River about $1 \mathrm{~km}$ west of the George C. Davis site. The W. T. Brooks Farm site lies about $10 \mathrm{~km}$ northwest of the George C. Davis site.

According to A. T. Jackson, in 1931 a portion of a ceramic elbow pipe was plowed from the upper levels of a midden deposit at the W. T. Brooks Farm site by the landowner, and then donated to the University of Texas. Near the midden were ancestral Caddo burials with ceramic vessels as associated funerary offerings, but Jackson did no work there. 
The pipe is a short-stemmed elbow pipe with incised lines (records on file at TARL). Such an elbow pipe is either a Var. B or var. C elbow pipe with several horizontal incised lines on the stem below the rim (see Perttula 2011:Figure 6-23). These pipes were made and used in the Late Caddo period Frankston phase, between ca. A.D. 1400-1560 for Var. B pipes and between ca. A.D. 1400-1650 for Var. C. pipes (Perttula 2011:215).

\section{Summary and Conclusions}

The R. F. Wallace Farm (41CE20) and W. T. Brooks Farm (41CE18) sites are ancestral Caddo settlements on southward-flowing tributaries, Bowles Creek and Box's Creek, respectively, of the Neches River in the East Texas Pineywoods. The University of Texas (UT) conducted archaeological investigations at the R. F. Wallace Farm site led by A. T. Jackson in 1932, after an ancestral Caddo burial with two vessels had been eroded from the site by flooding in 1930. They also examined a ceramic pipe fragment that had been donated to UT in 1931 from the W. T. Brooks Farm site, but did no excavations there.

The initial occupation of the R. F. Wallace Farm site was during the Woodland period (ca. 500 B.C.A.D. 800). This Mossy Grove culture occupation is marked by four sherds of sandy paste Goose Creek Plain, var. unspecified ceramics. A more substantial occupation took place during the Late Caddo period, Frankston phase, at the R. F. Wallace Farm, and the elbow pipe fragment from the W. T. Brooks Farm site also dates to the Frankston phase. At these sites, the occupations appear to have been farmsteads with associated burial features. One of the vessels found at the R. F. Wallace Farm is a Poynor Engraved bottle. The principal ceramic ware that can be associated with the Frankston phase occupation at the R. F. Wallace Farm site is Poynor Engraved, including var. Blackburn. This variety of Poynor Engraved was apparently made throughout the Frankston phase, but is most common in ca. A.D. 1480-1560 contexts; Poynor Engraved, var. $C$ is also present during this temporal interval (see Perttula 2011:Table 6-37).

The last ancestral Caddo occupation at the R. F. Wallace Farm took place during the Allen phase, perhaps from ca. A.D. 1680-1700. Key Historic Caddo Allen phase ceramic types present in the ceramic vessel sherd assemblage are likely early varieties of Patton Engraved-var. Freeman and var. Fair (Perttula 2011:286) - as well as Spradley Brushed-Incised. Two glass beads were also found in the habitation deposits at the site, but unfortunately the beads are currently missing from the TARL collections.

Comparisons of ancestral Caddo ceramic assemblages from sites on the Neches River, as well as on Bowles Creek and Box's Creek, that rely on use of grog vs. bone temper and various utility ware ceramic metrics indicate that the R. F. Wallace Farm site assemblage falls in Group II of the Allen phase (Table 3 ). The assemblage postdates ca. A.D. 1680, and is characterized by (1) a high proportion of sherds from vessels manufactured with grog temper, with a limited use of bone as a temper; (2) a low P/DR; (3) moderate proportions of brushed to plain sherds; and (4) moderate proportions of brushed to other wet paste sherds (especially the considerable numbers of brushed-incised sherds). 
Table 3. Ceramic sherd assemblage comparisons of Neche cluster sites on Bowles Creek and Box's Creek and the Neches River.

\begin{tabular}{|c|c|c|c|c|c|}
\hline Site & $\%$ Grog & $\%$ Bone & $\mathrm{P} / \mathrm{DR}$ & $\mathrm{B} / \mathrm{Pl}$ & $\mathrm{B} / \mathrm{OWP} * *$ \\
\hline \multicolumn{6}{|c|}{ Allen phase (ca. post-A.D. 1680) } \\
\hline \multicolumn{6}{|l|}{ Group I } \\
\hline$\overline{41 C E 293}$ & 98.1 & 5.6 & 0.12 & 7.50 & 5.70 \\
\hline 41CE43 & 96.1 & 3.9 & 0.17 & 4.91 & 6.08 \\
\hline 41CE477 & 98.5 & 1.5 & 0.37 & 2.25 & 7.02 \\
\hline 41CE474 & 97.1 & 2.9 & 0.30 & 3.08 & 9.25 \\
\hline 41CE291 & 97.4 & 2.6 & 0.30 & 1.94 & 1.84 \\
\hline \multicolumn{6}{|l|}{ Group II } \\
\hline 41CE48 & 84.2 & 27.7 & 0.31 & 2.43 & 5.48 \\
\hline 41CE20 & 96.2 & 9.3 & 0.35 & 2.36 & 2.05 \\
\hline $41 \mathrm{CE} 475$ & 89.5 & 10.5 & 0.40 & 2.07 & 7.60 \\
\hline 41CE476 & 91.2 & 9.2 & 0.45 & 1.77 & 7.0 \\
\hline \multicolumn{6}{|l|}{ Group III } \\
\hline $41 \mathrm{CE} 47$ & 95.6 & 13.1 & 0.71 & 0.94 & 1.34 \\
\hline 41CE485 & 94.9 & 17.5 & 0.87 & 0.88 & 1.37 \\
\hline 41CE486 & 94.1 & 19.0 & 1.06 & 0.72 & 1.26 \\
\hline \multicolumn{6}{|c|}{ Late Frankston phase (ca. A.D. 1560-1680) } \\
\hline \multicolumn{6}{|c|}{ Group III } \\
\hline $\begin{array}{l}\overline{41 \mathrm{CE} 19,} \\
\text { Northern } \\
\text { part of site }\end{array}$ & N/A & N/A & 0.82 & 0.78 & 1.90 \\
\hline \multicolumn{6}{|c|}{ Possible Middle Caddo occupation, ca. A.D. 1300-1400 } \\
\hline \multicolumn{6}{|l|}{ Group IV } \\
\hline 41CE289 & 82.1 & 17.9 & 1.38 & 0.49 & 2.38 \\
\hline 41CE481 & 77.4 & 22.6 & 2.00 & 0.26 & 1.31 \\
\hline
\end{tabular}

Sources: Perttula and Stingley 2017

$\mathrm{P} / \mathrm{DR}=$ plain to decorated sherd ratio; $\mathrm{B} / \mathrm{Pl}=$ brushed/plain sherd ratio; $\mathrm{B} / \mathrm{OWP}=$ brushed/other wet paste sherd ratio

If they can be relocated and investigated anew, the R. F. Wallace Farm and W. T. Brooks Farm sites have the potential to shed new light on the character of ancestral Caddo Frankston phase and/or Allen phase settlements in the Neches River basin in East Texas. This is because they both apparently have (or did in the early 1930s) preserved habitation deposits with ceramic vessel sherds and food remains as well as midden features. Their cultural context, and the likely ages of their Caddo occupations, can be better appreciated now that there have recently been a number of ancestral Caddo sites investigated in the Bowles Creek and Box's Creek valleys that can be readily compared to other Caddo assemblages in the Neches River basin. The presence of European glass beads at the R. F. Wallace Farm, which is a rare occurrence in Allen phase sites in the Neches River basin, also suggests that the impacts of European contact and interaction with Caddo peoples can be investigated through the study of the site's archaeological deposits. 


\section{Acknowledgments}

I thank Lauren Bussiere of the Texas Archeological Research Laboratory at The University of Texas at Austin for her help in accessing the collections from the R. F. Wallace site.

\section{References Cited}

Ellis, L. W.

2013 Woodland Ceramics in East Texas and a Case Study of Mill Creek Culture Ceramics. Bulletin of the Texas Archeological Society 84:137-180.

Hart, J.P.

2014 An Analysis of the Aboriginal Ceramics from the Washington Square Mound Site, Nacogdoches County, Texas. Volume I, Center for Regional Heritage Research, James Corbin Papers in Archaeology. Stephen F. Austin State University, Nacogdoches.

Jackson, A. T.

1932 Notes on Work Done, Cherokee County, Texas, R. F. Wallace Farm (Lee Hudson Place). MS on file, Texas Archeological Research Laboratory, The University of Texas at Austin.

Marceaux, P. S.

2011 The Archaeology and Ethnohistory of the Hasinai Caddo: Material Culture and the Course of European Contact. Ph.D. dissertation, Department of Anthropology, The University of Texas at Austin.

Perttula, T. K.

2011 The Ceramic Artifacts from the Lang Pasture Site (41AN38) and the Place of the Site within an Upper Neches River Basin Caddo Ceramic Tradition. In Archeological Investigations at the Lang Pasture Site (41AN38) in the Upper Neches River Basin of East Texas, assembled and edited by T. K. Perttula, D. B. Kelley, and R. A. Ricklis, pp. 145-320. Archeological Studies Program Report No. 129, Texas Department of Transportation, Environmental Affairs Division, Austin.

Perttula, T. K. and R. Z. Selden, Jr.

2014 Ancestral Caddo Ceramics in East Texas. Journal of Northeast Texas Archaeology 48:9-58.

Perttula, T. K. and K. Stingley

2017 Archaeological Investigations at the Walnut Branch (41CE47), Ross I (41CE485), and Ross II (41CE486) Sites, Cherokee County, Texas. Journal of Northeast Texas Archaeology 76:31-70.

Story, D. A.

1990 Cultural History of the Native Americans. In The Archeology and Bioarcheology of the Gulf Coastal Plain, Vol. 1, by D. A. Story, J. A. Guy, B. A. Burnett, M. D. Freeman, J. C. Rose, D. G. Steele, B. W. Olive, and K. J. Reinhard, pp. 163-366. Research Series No. 38. Arkansas Archeological Survey, Fayetteville.

Suhm, D. A. and E. B. Jelks (editors)

1962 Handbook of Texas Archeology: Type Descriptions. Special Publication No. 1, Texas Archeological Society, and Bulletin No. 4, Texas Memorial Museum, Austin. 